〔94〕末端にカルボニル基を有する低分子ポリビニル アルコールの $\mathrm{pH}$ 変化に伴う呈色反応

(1961 年 12 月 20 日受理)

$$
\text { 白石誠* }
$$

\begin{abstract}
要旨 アルデヒドを溶郕として重合した低分子量のポリビニルアルコール水溶液は $\mathrm{pH}$ の変化に伴

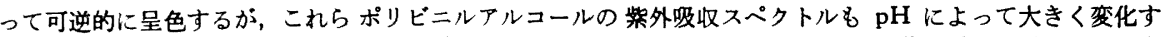
る。またモデル物啠として用いたへキサジェナールの $\mathrm{pH}$ の変化に伴5呈色反応, 紫外吸収スペクトルの変 化も，これらポリビニルアルコールと全く同じ挙動を示すことから，呈色反応と柴外吸収スペクトルの変化に は相関的な関倸が存在し，呈色には $-\mathrm{C}-(\mathrm{CH}=\mathrm{CH})_{n}-$ の $n=2$ 以上の共役不飽和系にある末端カルボニル基の $\stackrel{\text { Oे }}{0}$
\end{abstract}

榀造変化が関係しているものと思われる。

\section{1. 粕 言}

アルデヒド共存下に酢酸ビニル（VAc）を重合させて 得た，末端にカルボニル基 $(\mathrm{C}=0)$ を有する低分子量の ポリ酢酸ビニル (PVAc) をアルカリケン化して調製した ポリビニルアルコール (PVA) 水溶液は, アルカリ性に すると黄かっ色に呈色するがこれを酸性にすると無色と なり，この呈色反応は $\mathrm{pH}$ の変化によって可逆的である ことを認めた。

この $\mathrm{pH}$ 変化による呈色の変化は PVA の黄変問題 とも関連して興味深い現象であり，通常の PVA につい ては当研究所の上総1)により詳細に研究された。本研究 では特に末端に $\mathrm{C}=\mathrm{O}$ 基をもつ PVA テロマーを試料と して,この呈色反応を解明するため若干検討を加えた。

\section{2. 実験結果}

\section{$2.1 \mathrm{pH}$ 変化に伴う低分子量 PVA の呈色および紫} 外吸収スペクトル

VAc 70 モル\%，アセトアルデヒド 30 モル％，開始

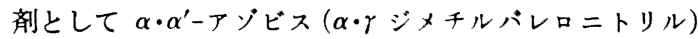
(AVN) を $0.5 \%$ (重量) 用い，封管中 $40^{\circ} \mathrm{C}$ で 48 時間 重合して得られた PVAc $\left(P_{A c}=53, C=0\right.$ 量 1.86 モル \%) を精製してメタノールに溶解し, 無水系で $50^{\circ} \mathrm{C}$, PVAc の基本分子あたり 0.5 モルのアルカリでケン化 した。得られた PVA を常法で精製して試料に供した。 本研究では重合度は中島式 ${ }^{2}, \mathrm{C}=\mathrm{O}$ 量は今井一上総の方 法帛に上って求めた。この $5 \%$ 水溶液に水酸化ナトリ ウム, 塩酸, 硫酸あるいは酢酸を加えて $\mathrm{pH}$ を順次変 えて可視的な呈色の変化を観察した。温度はいずれも室 温である。

その結果 $\mathrm{pH} 3.5$ の酸性では無色であり, $\mathrm{pH} 13$ の アルカリ性では微黄かっ色に変色する。これは添加する 酸の種類によらず $\mathrm{pH}$ のみによって呈色は可逆的であ

\footnotetext{
*合教レイヨン株式会社研究所 (网山県會数市酒津)
}

るのでプロトンの関与が考えられる。

ところが VAc 50 モル\%，アセトン 50 モル\%の溶 液組成で重合して得られた PVA では，pH の変化によ ってなんら呈色反応を示さなかった。したがってこの呈 色反応は同じ末端に $\mathrm{C}=0$ を有する PVA でも, アルデ ヒド共存下に得られたポリマー特有の反応であり, その 末端構造の相違によって起こっているものと考えられ る。

つぎに $\mathrm{pH}$ の変化による紫外吸収スペクトル (UV ス ペクトル）の変化を検討した。さきの PVA 水溶液を中 性 $(\mathrm{pH} 7.1) \rightarrow$ ルカリ性 $(\mathrm{pH}$ 13) $\rightarrow$ 酸性 $(\mathrm{pH} \mathrm{3.5)}$

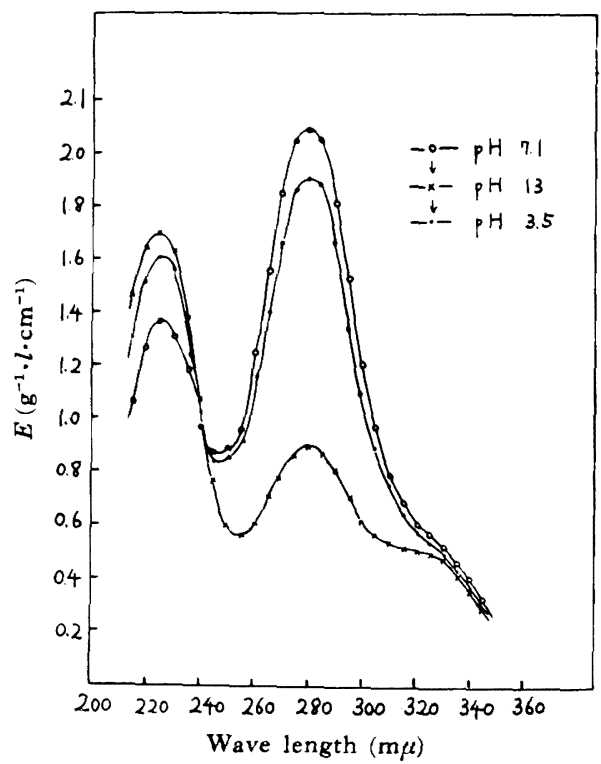

Fig. 1. Effect of $\mathrm{pH}$ on the ultraviolet absorption spectra of PVA derived from PVAc poly. merized in acetaldehyde (half an hour after $\mathrm{pH}$ was settled). 


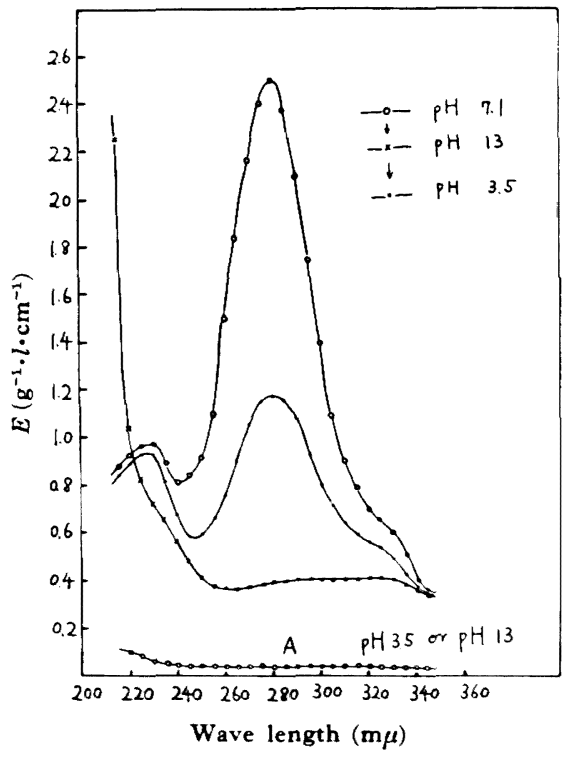

(A) PVA, derived from PVAc polymerized in acetone

Fig. 2. Effect of $\mathrm{pH}$ on the ultraviolet absorption spectra of PVA derived from PVAc polymerized in acetaldehyde ( 20 hours after $\mathrm{pH}$ was settled).

$\mathrm{pH}$ を順次変えた場合の UV スペクトルの変化を Fig. 1 に示した。水溶液の場合は $225,280 \mathrm{~m} \mu$ 付近に吸収の 山があり，これは山口ら”，烃本ららの報告のごとく末 端 $\mathrm{C}=\mathrm{O}$ の り $-\mathrm{CH}_{2}-\mathrm{CH}(\mathrm{OH})-$ 基の脱水によって生 した微量の $-\mathrm{C}-(\mathrm{CH}=\mathrm{CH})_{n}$-の $n=1,2$ に相当するもの O

と考えられる。

ところがアルカリ性 $(\mathrm{pH} \mathrm{13})$ にすると $280 \mathrm{~m} \mu$ の吸 収は小さくなり $225 \mathrm{~m} \mu$ の山は大きくなる。さらに酸 性 (pH 3.5) にすると再び $280 \mathrm{~m} \mu$ の吸収は増加し, $\mathrm{pH}$ 変化による可視領域の色の変化と UV スペクトルの変 化との間には相関的な関倸があるよ5に考えられる。

Fig. 1 は pH を変えた後おのおの約 30 分経過した のち測定したものであるが, $\mathrm{pH}$ 変化後 20 時間放固して から測定した結果を Fig. 2 に示した。Fig. 2 ではアル カリ性の場合 $280 \mathrm{~m} \mu$ の吸収はほとんど消失して $210 \mathrm{~m} \mu$ 付近に大きな吸収が新たに生成している。酸性の場合 $225 \mathrm{~m} \mu$ の吸収には変化がないが, $280 \mathrm{~m} \mu$ の吸収は両者 の中間にある。なおアルカリ性の場合透明な黄かっ色で あるのに酸性では全く無色となる。

このよ5な $\mathrm{pH}$ の変化に伴う PVA 水溶液の可視的 な呈色を考えると, より長波長側に新たな吸収が期待さ れたが, 少なくとも $700 \mathrm{~m} \mu$ まではそのような吸收の極 大は見られない（もちろん可視部においても透過率の
差は認められ，たとえば $6.40 \mathrm{~g} / l$ の檂度で $400 \mathrm{~m} \mu$ の 透過率はアルカリ性 $(\mathrm{pH}$ 13) で $59 \%$ に対し酸性 $(\mathrm{pH}$ 3.5) では $80 \%$ である)。

なおアセトンを溶剤として重合した PVAc より得た PVA の $\mathrm{pH}$ 変化に伴うスペクトルの変化もあわせて示 したがほとんど変化は認められない。また別に水酸化ナ トリウムのみの水溶液について UV スペクトルを測定 したが, $220 \mathrm{~m} \mu$ 以下に多少吸収が認められるけれども 吸光係数は無視しらる程度にきわめて小さい。

2.2 ヘキサジェナールの $\mathrm{pH}$ 変化に伴う UV スペク トルの変化

2.1 の結果より $280 \mathrm{~m} \mu$ の吸収の変化と呈色の間には 関係があるよ5に考えられるが、この吸收は $-\mathrm{C}-(\mathrm{CH}=$ II

$\mathrm{CH})_{2}$-によるものでないかと考え，モデル物質としてへ キサジェナール $\left(\mathrm{CH}_{8}-\mathrm{CH}=\mathrm{CH}-\mathrm{CH}=\mathrm{CH}-\mathrm{CH}\right)$ を合成し, II

その $\mathrm{pH}$ 変化に伴う可視的な変化と UV スペクトルの 変化をみた。

合成法は Kuhn ら ${ }^{6)}$ の方法に基いて行なった。すな わちクロトンアルデヒド $280 \mathrm{~g}$ (4モル) とアセトアルテ ヒド $352 \mathrm{~g}(8$ モル) をフラスコに入れ，つぎにピペリジ ン $6 \mathrm{~g}$ をかきまぜがら徐々に加えたのち, ピペリジン に対し $70 \%$ の割合に水酢酸を入れ 1 夜放置後口過す る。口液を $75 \sim 85^{\circ} \mathrm{C}$ の温度に 3.5 時間加熱し, さらに 口過する。口液をエーテル抽出後無水硫酸ナトリウムで

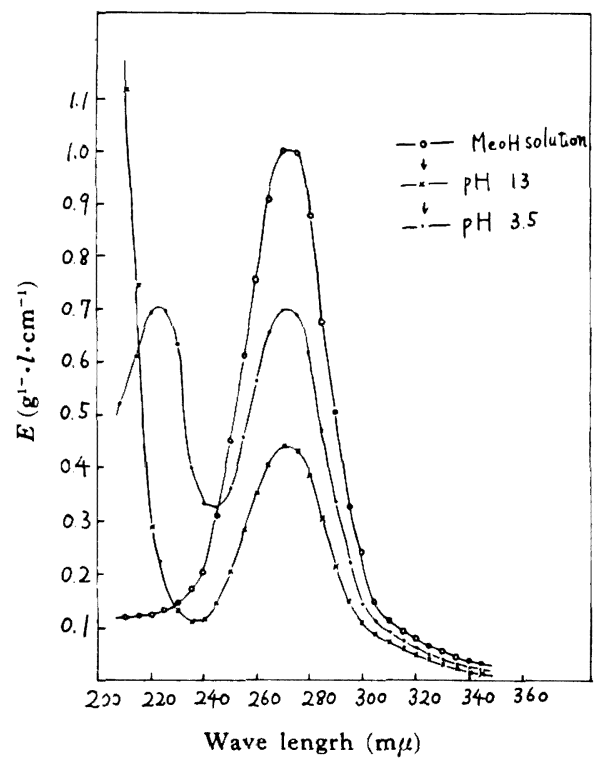

Fig. 3. Effect of $\mathrm{pH}$ on the ultraviolet absorption spectra of methanol solution of hexadienal (half an hour $\mathrm{pH}$ was settled). 


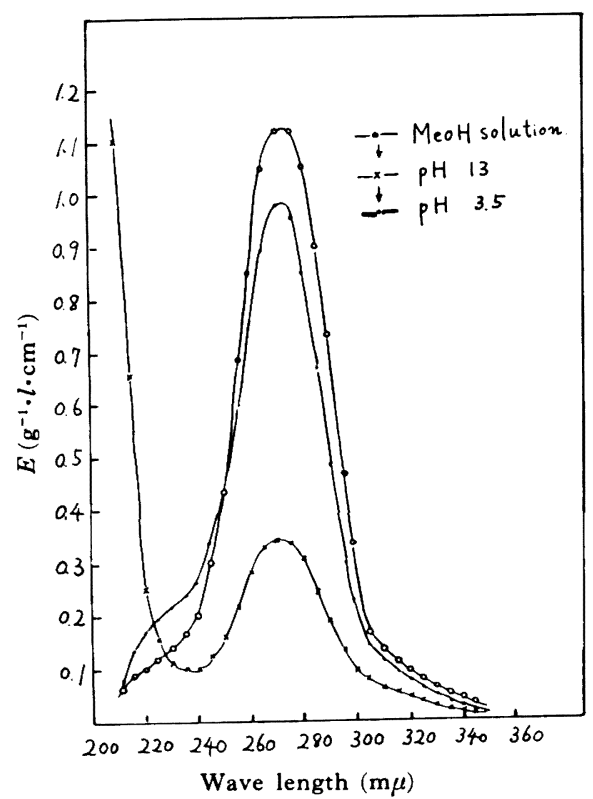

Fig. 4. Effect of $\mathrm{pH}$ on the ultraviolet absorption spectra of methanol solution of hexadienal (20 hours after $\mathrm{pH}$ was settled).

脱水して減圧蒸留した。粗留分を 再蒸留して $62 \sim 65^{\circ} \mathrm{C}$ (14 mmHg) の留分をとった。

これをメタノールに溶解しアルカリ性 $(\mathrm{pH} \mathrm{13)}$ にす
ると直ちに黄かっ色を呈し, 酸性 (pH 3.5) にすると退 色して無色となる。すなわちア七トアルデヒド中で重合 して得られた低分子量のPVA の挙動とみかけ上全く同 様である。

このへキサジェナールのメタノール溶液の $\mathrm{pH}$ 変化に 伴5 UV スペクトルの変化を Fig. 3 に示した。また Fig. 4 は $\mathrm{pH}$ を変化後 20 時間してから測定したもの である。いずれも $280 \mathrm{~m} \mu$ 付近の吸収はアルカリ性にす ることによって大きく低下し，220 $\mathrm{m} \mu$ 以下に 新たに大 きな吸収が生成する。またこれを酸性にすると $220 \mathrm{~m} \mu$ 以下の吸収極大はなくなり $280 \mathrm{~m} \mu$ 付近の吸収が再び大 きくなる現象も，全くさきの PVA の場合と同様であ る。

念のため初めから酸性 (pH 3.5) にした場合には, 吸 収には全く変化が認められない。この実験からさきの低 分子 PVA の $\mathrm{pH}$ による変化は，このへキサジェナー ルと同様に不飽和共役系にある $\mathrm{C}=\mathrm{O}$ の構造変化による ことがうかがえる。

\section{$2.3 \mathrm{pH}$ 変化による PVA 中のエノル型カルボニル 基の量}

前述のように $\mathrm{pH}$ 変化に伴う呈色の変化はポリマー末 端 $\mathrm{C}=\mathrm{O}$ の構造変化に関釈があることが予想されるが, $\mathrm{C}=\mathrm{O}$ は $\mathrm{pH}$ によってェノル化する可能性がある。もし エノル構造に変化しているとすれば，ポリマー中のエノ ル型カルボニル基の量を電導度滴定法によって定量する 場合，酸性にしておいてアルカリで逆滴定した值と，ア

Table 1. The amount of enol-form of $\mathrm{C}=\mathrm{O}$ group in PVA telomers measured by conductometric titration ${ }^{5)}$.

\begin{tabular}{|c|c|c|c|c|c|c|c|c|c|c|}
\hline \multirow{2}{*}{$\begin{array}{l}\text { Sample } \\
\text { number }\end{array}$} & \multicolumn{3}{|c|}{ Polymerization } & \multirow{2}{*}{$\bar{P}_{A c}{ }^{1)}$} & \multirow{2}{*}{$\begin{array}{c}\mathrm{C}=\mathrm{O} \text { of } \\
\mathrm{PVA} \\
(\mathrm{mol} \%)\end{array}$} & \multicolumn{2}{|c|}{ Enol form } & \multirow{2}{*}{$\begin{array}{c}\text { Standing } \\
\text { time }\end{array}$} & \multirow{2}{*}{$\begin{array}{c}\text { Difference } \\
\text { of acid } \\
\text { equivalent } \\
\text { (mol\%) }\end{array}$} & \multirow{2}{*}{$\begin{array}{c}\begin{array}{c}\text { Diff. of acid } \\
\text { equivalent }\end{array} \\
\mathrm{C}=\mathrm{O} \\
(\%)\end{array}$} \\
\hline & Aldehyde & $(\mathrm{mol} \%)$ & $\begin{array}{l}\text { Temp. } \\
\left({ }^{\circ} \mathrm{C}\right)\end{array}$ & & & $\begin{array}{c}\text { in acidic } \\
\text { side }^{2)} \\
\left(\mathrm{mol}^{\circ}\right)\end{array}$ & $\begin{array}{c}\text { in alkaline } \\
\text { side }^{3\rangle} \\
\left(\mathrm{mol}^{\circ}\right)\end{array}$ & & & \\
\hline $\mathrm{A}-\mathrm{A}-1^{\prime}$ & Acetald & 30 & 40 & 51 & 2.07 & 0.047 & 0.155 & $5 \mathrm{~min}$ & 0.108 & 5.2 \\
\hline$A-A-2$ & Acetald & 20 & 40 & 50 & 1.86 & 0.114 & 0.421 & $24 \mathrm{hr}$ & 0.307 & 16.5 \\
\hline $\mathrm{A}-\mathrm{A}-2^{\prime}$ & Acetald & 20 & 40 & 49 & 1.94 & 0.088 & 0.156 & $5 \mathrm{~min}$ & 0.068 & 3.5 \\
\hline $\mathrm{A}-\mathrm{A}-2^{\prime}$ & Acetald & 20 & 40 & 49 & 1.94 & 0.088 & 0.216 & $5.5 \mathrm{hr}$ & 0.122 & 6.3 \\
\hline $\mathrm{A}-\mathrm{A}-2^{\prime}$ & Acetald & 20 & 40 & 49 & 1.94 & 0.088 & 0.375 & $24 \mathrm{hr}$ & 0.281 & 14.5 \\
\hline B-A-2 & Buthyrald & 20 & 60 & 24 & 2.74 & 0.057 & 0.122 & $5 \mathrm{~min}$ & 0.065 & 2.4 \\
\hline B-A-2 & Buthyrald & 20 & 60 & 24 & 2.74 & 0.057 & 0.130 & $3.5 \mathrm{hr}$ & 0.073 & 2.7 \\
\hline $\mathrm{B}-\mathrm{A}-0$ & Buthyrald & 30 & 0 & 22 & 3.12 & 0.053 & 0.106 & $5 \mathrm{~min}$ & 0.053 & 1.7 \\
\hline B-A-0 & Buthyrald & 30 & 0 & 22 & 3.12 & 0.053 & 0.232 & $2.5 \mathrm{hr}$ & 0.179 & 5.7 \\
\hline \multirow[t]{2}{*}{ hexadienal } & & & & & & 4.20 & 7.25 & $5 \mathrm{~min}$ & 3.05 & 3.0 \\
\hline & & & & & & 4.20 & 21.0 & $24 \mathrm{hr}$ & 16.8 & 16.8 \\
\hline
\end{tabular}

1) $\bar{P}_{A c}, \mathrm{DP}$ of polyvinylacetate

2) Acidic solution of PVA telomer is titrated by alkali

3) Alkaline solution of PVA telomer is titrated by acid

4) Standing time from preparation of aqueous acidic or alkaline solution of PVA telomer till titration

5) The content is based on the monomeric unit 
ルカリ性にしておいて酸で逆滴定した值には差が生ずる ものと考えられる7。そこでアルデヒドを溶㓮として重 合した PVAcより得た低分子 PVA のエノル型カルボ ニル基の量を酸性あるいはアルカリ性の両側より求め た。結果を Table 1 に示した。

放置時間によって酸当量は増加する傾向にあるが、ア ルカリ性および酸性側から測定した值は明らかに相違が あり,この実験の範囲では 24 時間でポリマー末端 $\mathrm{C}=\mathrm{O}$ 量の約 $15 \%$ 程度の酸当量を得る。これはポリマー末端 $\mathrm{C}=\mathrm{O}$ がェノル型へ変化していることを示すものと考え られる。

またへキサジェナールについてもメタノール：水（1：

1）を溶凧にして同様な測定を行なったが, Table 1 に示 したようにアルカリ性の方が酸当量は高くエノル满造の 可能性を示している。

\section{3. 実験䊅果の考察}

アルデヒドを溶剂として重合した PVAc から得た末 端に $\mathrm{C}=\mathrm{O}$ を有する低分子 PVA の $\mathrm{pH}$ 変化に伴 5 呈 色の変化と, UV スペクトルの変化は前述の実験結果に 見られるように相関的な関係があり, ポリマー水溶液の 呈色反応は $\mathrm{pH}$ 変化に伴う末端 $\mathrm{C}=\mathrm{O}$ の構造変化と関俰 があることが推定される。

またモデル物質としてへキサジェナールについて $\mathrm{pH}$ 変化に伴ら呈色反応とUV スペクトルの関係を調へた 結果, 前記 PVA と全く類似の挙動を示すことが認めら れた。

このへキサジェナールの pH 変化による呈色, UV ス ペクトルの変化の挙動が, 末端に $\mathrm{C}=0$ を有する PVA と同じであるとは, 山口ら", 松本ら”によって見出され たごとく, 末端 $\mathrm{C}=\mathrm{O}$ の一部が $-\underset{\mathrm{O}}{\mathrm{C}}-(\mathrm{CH}=\mathrm{CH})_{n}-$ の $n=1$,

2, 3 のような不飽和楧造をとっていることを, 別の面よ りさらに確かめたことにもなるわけである。

また別に $n=1$ に相当するクロトンアルデヒド $\left(\mathrm{CH}_{3}-\right.$ $\mathrm{CH}=\mathrm{CH}-\mathrm{CHO})$ について $\mathrm{pH}$ 変化による呈色反応を試み たが，ほとんど可視的な変化は認められなかった。さら に $n=3$ に相当するオクタトリエナール $\left(\mathrm{CH}_{8}-\mathrm{CH}=\mathrm{CH}-\right.$ $\mathrm{CH}=\mathrm{CH}-\mathrm{CH}=\mathrm{CH}-\mathrm{CHO})$ を合成し, $\mathrm{pH}$ 変化に伴ら呈色 反応を試みたところ, アルカリ性 $(\mathrm{pH} \mathrm{13})$ の場合は黄 橙色に呈色するが酸性（pH 3.5）にすると無色になるこ とを認めた。したがってこの $\mathrm{pH}$ 変化による呈色反応 はこれらモテル物質の構造から考えて, ポリマー末端の 共役不飽和 $\mathrm{C}=\mathrm{O}$ が関係しており，しかも $n=2$ 以上の 不飽和構造を有するものに対応しているのではないかと 考えられる。

Fig. 2 に示したように $\underset{\mathrm{O}}{-\mathrm{C}}-\mathrm{C}-(\mathrm{CH}=\mathrm{CH})_{n}-$ の $n=1,2$ に
相当するとみられる $225,280 \mathrm{~m} \mu$ の吸収がアルカリ性 にした場合，ほとんど消失することは他の構造に変化し ているものと考えられる。電導度滴定法によってポリマ 一の酸当量を定量した結果から，アルカリ側，酸側で測 定した值は実験誤差以上に相違がみられ，アルカリ側の 方が高く 24 時間で末端 $\mathrm{C}=\mathrm{O}$ 量の約 $15 \%$ に相当する 酸当量を得た。このことは末端 $\mathrm{C}=\mathrm{O}$ の一部はエノル構 造をとっていることが推定され，呈色反応となんらかの 関係があることが考えられる。

筆者はさきにアルデヒド共存下に重合した末端に $\mathrm{C}=$ O を有する PVAc はアルカリ・ケン化にさいしケトン を脱離して大部分アルデヒド型になっていることを報告 しだ)。また Fig. 1 に示したよ5に, $\underset{\mathrm{O}}{-\mathrm{C}}-(\mathrm{CH}=\mathrm{CH})_{3}-$

によるとみられる $320 \mathrm{~m} \mu$ の吸収(1), は) は非常に小さいの で, 試料ポリマー中にはこのよらな構造はほとんどない と考えられ, 呈色の原因は $(\mathrm{CH}=\mathrm{CH})_{2}-\mathrm{CH}$ の変化が II

主であるように思われる。すなわち $\underset{\mathrm{O}}{-\mathrm{C}}-(\mathrm{CH}=\mathrm{CH})_{n=1,2}$

に相当するとみられる $225,280 \mathrm{~m} \mu$ の特性吸収はェノル 型に変化することによって消失し, 代わって $-(\mathrm{CH}=$ $\mathrm{CH})_{n 1,2^{-}}$結合による短波長側への 極大吸収の 移行が生 ずるものと考えられる。

またアセトンを溶剤として重合した PVAc から得た PVA では<smiles>CCC(O)CCC(C)=O</smiles>

のように $\mathrm{C}=\mathrm{O}$ とヒドロキシル基間に 2 個のメチレン基 を含むと考えられるので， $\gamma$-ヒドロキシカルボニル基の 分子内脱水反応による不飽和棈造をとりにくく，これが ため $\mathrm{pH}$ による呈色反応が起こりにくいのではないか と思われる。末端に $\mathrm{C}=\mathrm{O}$ を有する低分子 PVA の $\mathrm{pH}$ 変化に伴ら可視部の呈色と UV スペクトルの変化の間 には密接な関係があるものと思われるが、この点につい てはさらに検討を加え明確にしたいと考える。

付 記：ご指導いただきました当所次長松本昌一博士，本 研究の発表を許可された会社当局および実験に協力された守屋 四郎，藤沢稳彦君に感毁します。

\section{文献}

1）上総雄二郎：未発表

2) 中島章夫, 古館勝正：高化, 6, 460(1949)

2) 今井清和, 上総雄二郎：高化, 15, 249(1958)

4) 山口 格, 天笠正孝ら：高化，16, 571(1959)

5) 松本昌一, 今井清和ら：高化, 15, 255(1958)

6) Kuhn. B. et al.: Ber., 69, 98(1936)

7) 白石 誠, 松本昌一：高化，16，344(1959)

8) 白石 誠: 第 9 回高分子年次大会 (昭和 35 年 5 月 大阪) で発表 (高化投稿中) 


\title{
The Reversible Discoloration Reaction of Polyvinylalcohol Aqueous Solution by $\mathrm{pH}$
}

\author{
By Makoto Shiraishi*
}

The aqueous solution of the polyvinyl alcohol (PVA-I) derived by alkaline methanolysis of polyvinyl acetate polymerized in the presence of aldehyde showed a reversible color change with the change of $\mathrm{pH}$, yellow brown in alkaline and colorless in acidic state.

However, the polyvinyl alcohol (PVA-II) derived from polyvinyl acetate polymerized in the presence of acetone was colorless, even in alkaline state.

Spectroscopic study was carried out about PVA-I, PVA-II, and 2,4-hexadienal. From the resemblance of spectroscopic behavior between PVP-I and 2,4-hexadienal, it was considered that the course of color change of PVA-I was due to the tautomeric keto-enol isomerization of terminal carbonyl group.

\footnotetext{
* Resarch Laboratory Kurashiki Rayon Co., Ltd. (Sakazu Kurashiki Okayama)
} 